\title{
Freedom of Arts as an Independent Fundamental Right in the Hungarian Legal System
}

\begin{abstract}
ANDRÁs KOLTAY*
Abstract. The paper discusses the issue whether art and works of art created by artists can be assessed using legal means. The paper provides an overview of the different Hungarian constitutional provisions governing artistic freedom from 1949 to the present, and examines the possible components of freedom of arts as a fundamental right, within the confines of the Hungarian legal system. According to the author, the subjective side of the artistic freedom integrates into the fundamental right of freedom of expression, ie artistic expression is free, but it does not require a separate, specific protection under constitutional law. However, the specificities of artistic expression as factors influencing the scope of the freedom of expression might be taken into account, e.g. symbolic speech, the specificities of a genre or the time elapsed since publication). Hence, works of art and literary pieces are to be treated as specific, unique forms of opinions - they are presented as a form of freedom of expression but this does not go beyond the boundaries of freedom of expression as a fundamental right. At the same time, the regulation of art, irrespective of this, might be justified even in the Fundamental Law. Setting requirements for the state (the objective obligation of the state to safeguard the institutions of fundamental law) is a precondition for the birth and preservation of works of art, which constitutes the objective side of artistic freedom without any specific subject and denotes its specific constitutional content But, an appropriate level of protection for freedom of expression ensures that this recognition should not have any detrimental consequences for freedom of arts.
\end{abstract}

Keywords: freedom of expression - freedom of arts - Fundamental Law of Hungary

\section{INTRODUCTION}

Can art and works of art created by artists be assessed using legal means? Is it possible for works of art, which embody the greatest achievements of the human spirit and through which each era defines its own culture, to be judged by the law, a deliberately down-toearth, technical set of rules which aims to settle great or small disputes between citizens or between citizens and the state?

The scope of individual freedom today is broader than ever before during the history of mankind especially when it comes to issues of morality and freedom of opinion and as such, artists and writers living under the legal systems of the Western World face few serious or persistent challenges. Nevertheless, it is still true that certain general legal norms still apply to works of art, even though greater freedom is allowed to the individual than ever before. In this paper, it will be argued that this is not necessarily a problem. The 'absorption' of artistic freedom into the fundamental right of freedom of expression and the simultaneous acknowledgement of the lack of any need to protect it separately, were unavoidable for many reasons. At the same time, an appropriate level of protection for freedom of expression ensures that this recognition should not have any detrimental consequences for freedom of arts, which, aside from constitutional terminology or the doctrines surrounding fundamental rights, is surely one of the most important achievements and values of our civilisation.

Section 2 provides an overview of the different Hungarian constitutional provisions governing artistic freedom from 1949 to the present, while section 3 examines the possible

* Associate Professor, Pázmány Péter Catholic University, Budapest, koltay.andras@jak.ppke. hu. 
components of freedom of arts as a fundamental right, within the confines of the Hungarian legal system. The paper ends in with some conclusions in section 4.

\section{REGULATION OF ARTISTIC FREEDOM UNDER THE CONSTITUTION}

Article 53 of the first fundamental law of Hungary, the Constitution of 1949, stipulated that 'the Hungarian People's Republic provides effective support ... to art depicting the life and struggles of the people, reality and celebrating the victory of the people'. The original wording of the constitution thus failed to mention artistic freedom, instead prescribing the State's commitment to support an ideologically restricted category of artworks. ${ }^{1}$

Article 60 of the Constitution was amended, as a result of the constitutional reform implemented by Act I of 1972, to include the right to artistic freedom (the 'Hungarian People's Republic ensures the freedom of academic and artistic activities') although the state's supporting activity remained in the text (namely in Article 18), in a similarly narrow scope: 'the Hungarian People's Republic ... helps art in the service of progress'.

Article 70/G of the Constitution (added following the end of the communist regime in Hungary), that was in force until 2012, expressly provided for the freedom of 'artistic life', together with that of 'scientific life', in line with democratic requirements:

1) The Republic of Hungary shall respect and support the freedom of scientific and artistic life, the freedom of learning and of teaching.

2) Only scientists shall be entitled to decide on questions of scientific truth and to determine the scientific value of research.

Since 2012, Article X of the Fundamental Law is similar in content, albeit using different, somewhat more loquacious terminology declaring the freedom of 'artistic creation' (as well as of 'scientific research'). The only real change is that the Hungarian Academy of Sciences and the Hungarian Academy of Arts (a formerly private association transformed into a public body) were granted constitutional rank.

1) Hungary shall ensure the freedom of scientific research and artistic creation, the freedom of learning for the acquisition of the highest possible level of knowledge and the freedom of teaching within the framework determined by law.

2) The State shall not be entitled to decide on questions of scientific truth and scientists shall have the exclusive right to evaluate any scientific research.

3) Hungary shall defend the scientific and artistic freedom of the Hungarian Academy of Sciences and the Hungarian Academy of Arts. All institutions of higher education shall be autonomous in terms of the contents and methodology of research and teaching and their organisations and financial management shall be regulated by a special Act. The Government shall, within the framework of an Act, lay down the rules governing the management of public higher education institutions and shall supervise their management.

It is primarily the Constitutional Court's (Alkotmánybíróság, abbreviated as AB when referring to its resolutions) decisions that provide some guidance regarding the place and 
content of freedom of arts within the system of fundamental rights. Constitutional Court decision no 30/1992. (V 26.) AB, primarily dealing with the criminal law assessment of hate speech, placed artistic freedom into the subcategory of 'communications-related fundamental rights', as an independent fundamental right stemming from freedom of expression, the latter being a 'mother right'.

[T] he freedom of expression has a special place among constitutional fundamental rights. In effect it is the 'mother right' of several freedoms, the fundamental rights of 'communication'. The rights named as deriving from this 'mother right' are the right to free speech and the right to the freedom of the press, with the latter encompassing the freedom of all media, as well as the right to be informed and the right to obtain information freely. In a broader sense, freedom of expression includes artistic and literary freedoms, the freedom to distribute and disseminate works of art, the freedom of scientific research and the freedom to teach scientific knowledge. ${ }^{2}$

Constitutional Court decision no 24/1996. (VI. 25.) AB expressly focused on artistic freedom. The Constitutional Court annulled certain provisions of a Council of Ministers Decree of 1982, which ruled that business entities, non-governmental organisations and organisations without legal personality could only acquire, use or market works of art after the work concerned had been assessed in terms of its artistic merits, which clearly violated the freedom of artistic life. The Constitutional Court stated

According to the position taken by the Constitutional Court, the freedom of artistic life, as a fundamental right, also includes the freedom of artistic creative work, the self-expression of the artist, free from any illicit restriction, as well as the freedom to display, present and distribute the works of art to the public ... As an inherent characteristic of art, the work of art is usually intended for and aimed by its author at the public (ie the audience). Hence, any regulation aiming to restrict access to the works of art jeopardises the freedom of artistic life. Based on the above outlined considerations, the core content of the freedom of artistic life lies in the right to pursue artistic creative work free from any kind of power-based influence, to express the opinion embodied in the work of art freely and hence to publish and present the works of art to the public. ${ }^{3}$

The requirement stating that works of art can be acquired (marketed, used) only after their assessment in terms of their artistic merits constitutes a violation of the general freedom of action. ${ }^{4}$

\section{FREEDOM OF ARTS AS A FUNDAMENTAL RIGHT}

\subsection{Regulations Governing Art}

Without a doubt, the State does have certain regulatory duties, which may be stated even in the Constitution. For example, copyright regulations are essential for the creation of artistic

2 Statement of Reasons, s III.2.1.

3 Statement of Reasons, s II.1.

4 Statement of Reasons, s II.2. 
or literary works. Similarly, the organisation of arts training and education is primarily a state duty, as is the financing of museums, exhibition spaces, etc.

The state has a twofold role in connection with the arts. One is being the obligor of fundamental rights, it must refrain from any interference in artistic freedom. The other is that it has a positive obligation to finance the network of institutions which promote the creation of works of art as well as to carry out direct sponsorship (patronage) activity. Accordingly, artistic freedom, as a fundamental right, is a Janus-faced freedom. On the one hand it is a classic civil liberty, where the artist (writer) is the rights holder while the State is obliged to refrain from interfering and on the other hand, artistic freedom requires the active participation by the state in the field of artistic life.

\subsection{The Need for the State's Participation, Involvement and Commitment in the Arts}

\subsubsection{The State's Obligation of Objective Institutional Protection}

The theory of 'the obligation of objective institutional protection' has been shaped by the practice of the Constitutional Court in Hungary. The Constitutional Court, in decision no 64/1991. (XII. 17.) AB, passed in the second year of its operation, laid down the following principles:

[D]ue to the different aspects and duties of the rights holder of the fundamental right and of the state, the subjective right and the objective side of this fundamental right do not necessarily overlap. The state, as a result of its general and objective considerations, may define the scope of objective, institutional protection of the same fundamental right beyond the scope of protection afforded to it on the basis of the subjective right. ${ }^{5}$

The State's obligation to protect human rights has a dual nature based on the general framework provided by human rights regulations. On the one hand, the state protects the human rights guaranteed to individuals (legal subjects), whilst on the other hand, in certain cases - with respect to specific human rights - it ensures the conditions necessary for the exercise of human rights (institutional protection). The institutional protection of a certain human right may provide a justification for restricting another. According to Zsolt Balogh:

[T]he state, acting within the framework of its obligation of institutional protection attached to the fundamental right, may afford similar protection as that ensured by the given fundamental right as a subjective right ... Hence, even if no rights are guaranteed to the individual on the grounds of the subjective right, the constitutional protection granted on the grounds of the fundamental right still holds. ${ }^{6}$

The quoted 'first abortion decision' was probably the most radical in recognising the institutional protection of rights. The decision did not recognise the right of the foetus to life, as it could not be inferred from the Constitution that a foetus is a human being and that as such it would be the subject of fundamental rights, it nevertheless defined the state's obligation of institutional protection regarding the very same right. Hence, according to the

\footnotetext{
5 Constitutional Court decision no 64/1991. (XII. 17.) AB, Statement of Reasons, s C.3.c).

${ }^{6}$ Balogh (1999) 34.
} 
Constitutional Court, the right to life has an objective side, even if it lacks a subjective side. This approach was confirmed by the 'second abortion decision'. ${ }^{7}$

The state's obligation, according to the Constitutional Court to ensure institutional protection also holds with respect to freedom of opinion and the freedom of the press, which means that the State is required not only to guarantee the freedom of the expression of opinion to its citizens but also to ensure the appropriate functioning of democratic public opinion. ${ }^{8}$ Back in the 1990s, the Constitutional Court established the state's obligation of institutional protection of fundamental rights in terms of the right to a clean and healthy environment, ${ }^{9}$ the freedom of conscience and religion ${ }^{10}$ and later in connection with the provision protecting human dignity in media regulation. ${ }^{11}$

This kind of positive state obligation can also be identified regarding artistic freedom as a fundamental right. The state has a responsibility and obligation to preserve its artistic heritage and to promote and facilitate the creation of new works of art.

The state may support art and can also enter the art market as a buyer. In doing so, it will be forced, by necessity, to make some value judgements. It will promote certain artists via the institutional system established for that purpose, whereas it will neglect others and it will decide which works should be purchased for public collections. Hence, by spending money, the state expresses a certain opinion. Money can be considered here as a special from of 'expression' and not only in this context. For instance, the sponsorship of the campaigns of certain political candidates during an election can similarly be considered as an 'expression'. ${ }^{12}$ If, during the early 1970s the Hungarian State had not purchased the Csontváry estate from Professor Gerlóczy, saved by him under adventurous circumstances, the paintings would probably have been lost for good. The state (and hence the audience) would have been one great collection poorer. This decision by the state also represented a clear value choice, made despite art critics and art historians not having a high opinion of Csontváry during his life and for a long time after his death.

In order to promote the arts, the Hungarian State maintains a complex network of institutions composed of numerous elements, thereby fulfilling its obligation of objective institutional protection. The state established the Hungarian Academy of Arts, also mentioned in the Fundamental Law, operating as an independent public body, in order to (according to the preamble of the respective Act) 'protect and increase cultural values, to protect art and historical traditions, to strengthen the high quality community environment of artistic creation and to protect the freedom of artistic creation in order to honour the remarkable achievements of the representatives of Hungarian artistic life'. ${ }^{13}$ It also

7 Constitutional Court decision no 48/1998. (XI. 23.) AB.

8 Constitutional Court decision no 30/1992. (V. 26.) AB, Statement of Reasons, s III.2.2; Constitutional Court decision no 37/1992. (VI. 10.) AB, Statement of Reasons, s II.2.a).

9 Constitutional Court decision no 28/1994. (V. 20.) AB, Statement of Reasons, s III.3.

10 Constitutional Court decision no 4/1993. (II. 12.) AB, Statement of Reasons, s A)I.2.b); Constitutional Court decision no 22/1997 (VI. 25.) AB, Statement of Reasons, s III.1.4.

11 Constitutional Court decision no 46/2007. (V. 27.) AB, Statement of Reasons, s V.2; Constitutional Court decision no 165/2011. (V. 20.) AB, Statement of Reasons, s IV.2.2.2.

12 As for the practice applied in the United States, see e.g. Buckley $v$ Valeo 424 US 1 (1976), more recently: Citizens United v Federal Election Commission 558 US 310 (2010). Of the decisions of the European Court of Human Rights, see Bowman $v$ the United Kingdom, case no 141/1996/760/961, judgement of 19 February 1998.

13 Act CIX of 2011 on the Hungarian Academy of Arts. 
established the National Cultural Fund of Hungary in order to support artistic and literary works, ${ }^{14}$ the Hungarian National Film Fund to promote cinematographic works ${ }^{15}$ and the Hungarian Media Patronage Programme. ${ }^{16}$ The state maintains or recognises institutions of higher education providing education in the arts ${ }^{17}$ while protecting works of art and cultural assets created in the past, ${ }^{18}$ and separately provides for the legal status of performing artists. ${ }^{19}$

The establishment of this institutional system necessitates that certain value choices be made and its continuous operation requires day-to-day value judgements, wherein the state has the opportunity to enforce the criteria by which it wishes to spend finite, available resources assigned for that purpose. It is the obligation of the State under the Constitution to establish this independent institutional framework. This also highlighted by Constitutional Court decision no 51/2007. (IX. 15.) AB, made in connection with a minor issue, namely the social security and social support related status of artists: 'Artistic creation, due to its inherent nature, has always demanded a special legal framework, since this activity can hardly be fitted into the group of other work-related legal relationships. Hence, the special characteristics of this activity had to be taken into account, in particular in the course of shaping and operating the social care system.' ${ }^{20}$

\subsubsection{State Neutrality and Pluralism}

Government bodies cannot act in a value-neutral manner in their decisions related to the arts, since such a requirement would make it impossible to operate a system dedicated to protecting the institutions. However, this remains a very sensitive issue. It should be avoided at all costs that the State or any of its bodies should force the value choices they were required to make onto its citizens. The principle of state neutrality thus does not narrow the state's latitude in making decisions assigned to its competence, as these issues have to be decided on in any case, rather it imposes an obligation on the State to refrain from interference in the relationship between the state and its citizens.

The constitutional principle of neutrality, which was first reinforced in connection with religious beliefs, means that the state must recognise different ideologies and value judgements as equal. ${ }^{21}$ However, the principle of neutrality can only be maintained while it ensures that everyone has the right to choose freely from the views and ideologies available to them and so the state is not allowed to apply any coercion to anyone in their decisionmaking. Even so, the state can never become completely independent and so the principle does not require the state to be indifferent. The Constitutional Court states 'the fact that the state itself is neutral does not imply a negative freedom of religion and still less the promotion of religious indifference'. ${ }^{22}$ The requirement of pluralism does not mean that the

14 Act XXIII of 1993 on the National Cultural Fund of Hungary.

15 Act II of 2004 on Motion Pictures.

16 Act CLXXXV of 2010 on Media Services and Mass Media. See Kollarik and Vincze (2016) $53-76$.

17 Act CCVI of 2011 on National Higher Education.

18 Act LXIV of 2001 on the Protection of Cultural Heritage.

19 Act XCIX of 2008 on the Support and Special Employment Rules of Performing Arts Organisations.

20 Statement of Reasons, s III.1.

21 On this matter, see Kis (1997).

22 Constitutional Court decision no 4/1993. (II. 12.) AB, Statement of Reasons, s I.1.c). 
state is not allowed to define priorities based on ideological grounds but rather that it cannot demand exclusivity and cannot say that only the ideologies and value judgements preferred by it are correct.

An individual is not born into a vacuum, without any recognised values. The cultural environment surrounding the individual provides the possibility of a choice between values - enabling choice between the various alternatives is one of the key tasks of the state. It can be argued from among the various alternatives, that it is also the task of the state to support, with greater emphasis than the other possible choices, those alternatives that represent the characteristic values of its citizens.

Decisions on matters such as what days should be declared state holidays; what should be taught in schools or whether a Ministry of Culture should be established or not all involve value judgements and all are absolutely necessary and desirable. ${ }^{23}$ Libraries and art galleries should be worth maintaining even if only a few people were interested in them. Various items of value, deemed worthy of preservation on the basis of a public consensus reached in the past, require protection even if the given consensus no longer exists or is currently debated by many people.

The State neutrality principle also covers the State's attitude to art. According to Constitutional Court decision no 18/2014. (V. 30.) AB:

As far as the freedom of artistic life is concerned, the State has an obligation of objective institutional protection which entails that it shapes the legal and organisational conditions required to ensure the individual fundamental rights by simultaneously taking into account all of its other related fundamental rights and constitutional duties. It shall ensure the most favourable enforcement of the individual rights, always with a view to the whole system and it thereby promotes harmony between the fundamental rights as well.' (Constitutional Court decision no 64/1991. (XII. 17.) AB) The harmony between the fundamental rights can only be ensured by the State's neutrality in matters related to the arts - the State must allow and guarantee the diversity of artistic creation, without granting exclusivity to a single trend or approach. $^{24}$

However, as already noted above, this obligation is not incompatible with the decisions that need to be made in order to allocate state funds or perform other state duties. The issue of statues erected in public areas is an example of these decisions. Hungary has a long tradition of wars waged over the politics of memory in connection with statues. ${ }^{25}$ Nevertheless, it is beyond dispute that in any constitutional system it is ultimately the state or, more frequently, the competent municipality that can make the decision on the erection or demolition of a statue in a public area.

While recognising their right to make necessary value judgements, government bodies must also respect the principle of pluralism. The obligation of the state to contribute, via its institutional system, to the pluralism, diversity and variety of artistic life constitutes an important element of the obligation of the state to protect the institution of artistic freedom as a fundamental right. This is an obligation similar to that related to the pluralism of the

23 Levinson (1998) 195-220.

24 Statement of Reasons, para 14. For the general evaluation of the decision, see Cseporán and Kocsis (2014).

25 For a unique overview of this matter, see Pótó (2003). 
media market (the marketplace of ideas). ${ }^{26}$ Upon completion of the review of the constitutionality of the Act establishing the Hungarian Academy of Arts, the Constitutional Court summed up the matters as follows:

[I]n order to meet the requirement laid down in paragraph (1) of Article $X$ of the Fundamental Law, the Hungarian Academy of Arts, operating in the form of a public body, must afford due protection to the freedom and diversity of artistic creation and also to its different trends and tendencies, without violating the values of the Fundamental Law. This requirement must be respected by the legislator as well, in the course of establishing the rules governing the membership structure and activities of the Hungarian Academy of Arts. Whereas the public body itself must reflect and promote the pluralism of artistic activities through its organisational structure and operation. The Hungarian Academy of Arts must ensure equal opportunities to artists in becoming members of the Hungarian Academy of Arts and, through this, it must also ensure that the artists are able to have some influence on artistic life. ${ }^{27} \ldots$ Based on this, Article 7(2) of the Act on the Hungarian Academy of Arts, which stipulated that only the members of a specific civil society organisation could have become full members of the Hungarian Academy of Arts upon its establishment and on the Board having exclusive competence regarding the admission of future members, was not in full accord with the requirement of neutrality and pluralism aimed to ensure the freedom of artistic creation. This did not fully comply with the provisions of paragraphs (1) and (3) of Article X of the Fundamental Law. ${ }^{28}$

The state therefore has a multifaceted personality in terms of its relation to the arts. On the one hand, it is obliged to make certain value judgements, in the field of funding and purchases, whilst on the other hand, depending on its economic resources, it must make efforts to maintain a pluralistic artistic life and to increase diversity. This, in fact, is not an unresolvable contradiction. A well-functioning state can separate these two roles by having a properly designed institutional system equipped with decision-making rights delegated to different places and by resorting to expert assistance on a continuous basis.

\subsection{Scope of Freedom of Arts as a Subjective Right}

Is freedom of arts an independent right, with content separable from other fundamental rights? If it is considered that freedom of arts is included in a separate, independent Article of the Fundamental Law (and also in the former Constitution), it may be inferred that the legislator wished to define it as an independent right. However, art, as a social phenomenon, is worthy of independent protection for many reasons and hence to be defined specifically in constitutions, does not necessarily mean that artistic freedom is a broader freedom or that it has a different nature to the freedom of expression, which undoubtedly is an independent freedom, with a unique fundamental right content.

There are other reasons can also be listed to prove the independence of artistic freedom. Beyond the fundamentally textual argument that it appears separately in the Fundamental Law, Art is clearly of great importance and not only in terms of its capacity to ensure the

26 Constitutional Court decision no 37/1992. (VI. 10.) AB.

27 Constitutional Court decision no 18/2014. (V. 30.) AB, Statement of Reasons, para 16.

28 Constitutional Court decision no 18/2014. (V. 30.) AB, Statement of Reasons, para 22. 
self-expression of individuals but also in the interest of society as a whole. Enjoying art is not merely an intellectual entertainment or a pleasant pastime but greatly contributes to the development of an individual's intellectual potential and of their views on various important questions of life. All this ultimately enriches the community.

Some argue that freedom of speech should never be limited in the case of artistic expression and therefore they do not accept such a limitation, even for the sake of protecting public morals, 'artistic freedom excludes, by definition, its assessment from the viewpoint of public morals' ${ }^{29}$ A textbook on fundamental rights argues that although artistic freedom is not unrestrictable, 'science and art, as means of self-expression, are the freest fields of the right to free expression' ${ }^{30}$ and hence 'in certain cases these are afforded a protection broader than that of the general freedom of expression'. ${ }^{31}$

Those representing these standpoints do not systematically attempt to separate cases of the freedom of opinion and artistic freedom and as we will see later, jurisprudence has been developing in the opposite direction, ie the uniform judgement of the two rights.

A theoretician of artistic freedom as a fundamental right encounters the problem of having to define the concept of 'art' if they wish to lay the theoretical foundations of granting a specific protection to artistic freedom. For the lawyer, this is surely an impossible task and any such attempt is bound to be cumbersome and unnatural, producing a field of manoeuvre that is either suffocatingly narrow or unmanageably loose. This is because art is a much more complex, uncertain and permanently changing phenomenon without any social context, rather than letting itself be shackled by legal concepts (and fortunately so). In addition, any (legal or non-legal) definition would need to have an element of aesthetic assessment and putting lawyers in charge of assessing the aesthetic value of works of art is to be avoided at all costs, even if it is limited to drawing the distinction between what qualifies as art and what does not. ${ }^{32}$ Oliver Wendell Holmes, the legendary judge of the US Supreme Court stated at the beginning of the twentieth century that 'It would be a dangerous undertaking for persons trained only to the law to constitute themselves final judges of the worth of pictorial illustrations, outside of the narrowest and most obvious limits.' 33 Fortunately, the law currently stops where natural laws, ie the specificities of the regulated phenomenon, make it stop. Not even copyright law defines the concepts of 'science, literature and art' but requires the piece to be 'unique, original' for its author to be granted protection. ${ }^{34}$

The definition of art is therefore uncertain from a legal perspective. If the author of a given work of art or literary work considers their work to be art or literature, this consideration cannot be challenged, questioned or disputed in a legal sense. If the 'individual, original' character of the creative product considered as a work of art is missing then that shall exclude protection by copyright, but it does not constitute a clear, legal statement or position meaning that the creative product 'does not qualify as art'. It is a question, for example, whether the famous urinal by Marcel Duchamp had any individual, original character in the eyes of his contemporaries. If a specific, more powerful protection was provided to works of art compared to the protection afforded to freedom of opinion,

29 Halmai (1994) 273-74.

30 Zeller (2006) 592.

31 Zeller (2006) 600.

32 Sólyom (2007) 109.

33 Opinion of Justice Holmes, Bleistein v Donaldson Lithographing Co 188 US 239, 251 (1903).

34 Act LXXVI of 1999 on Copyrights, Article 1(3). 
then given that in a legal procedure it is not possible to define art, practically any expression perceivable to the external world could qualify as 'creation' and 'art' and this could not be disputed by a third party and thus it could require immunity solely based on a decision of its creator and not based on its really distinct substantive or formal specifics, because, in the absence of a definition, these aspects cannot be judged in a legal procedure.

Going beyond the difficulties in defining art it may nevertheless be worth attempting to identify the potential content of artistic freedom. According to the decision of the Constitutional Court referred to earlier, dated 1996, 'the freedom of artistic life, as a fundamental right, also includes the freedom of artistic creative work and the self-expression of the artist, free from any illicit restriction, as well as the freedom to display, present and distribute works of art to the public' ${ }^{35}$ Accordingly, the content of the right can be divided into two partial rights. In chronological order, the freedom of creation (self-expression) comes first and is followed by the freedom to make the finished work of art public (presentation, distribution).

It should be noted that the process up until the creation of the work of art is completed the birth of the idea, acquisition of necessary raw materials, the process of creation cannot be granted any specific legal protection. The right to 'the freedom of thought' can be used as an analogy as it is stipulated in various legal documents but which is without substantive real content related to a fundamental right. According to the Constitutional Court, freedom of thought also includes the freedom of conscience and the freedom of religion as specific, partly separate areas. ${ }^{36}$ However, the Constitutional Court does not mention this as a fundamental right derived from the mother right of the freedom of expression, as opposed to the other two rights. ${ }^{37}$ It would be difficult to attribute constitutional legal interpretation as only an already expressed, perceivable thought, ie exercising the right to freedom of opinion can be legally relevant. ${ }^{38}$ As such, the freedom of thought is merged with freedom of opinion and the freedom of conscience and religion, perhaps in certain cases with the protection of privacy. it is not justified to provide separate protection for it in constitutions and conventions. The same applies to 'the first partial right' of artistic freedom - the creator cannot be granted legal protection prior to the perceivable appearance of the work of art for practical reasons. The acquisition of the raw materials, tools and equipment required by the artist to produce the work of art is already granted protection through the general freedom of action of the artist (human dignity) so no specific separate constitutional protection is necessary for this purpose.

The second partial right, the right of presentation and distribution, is protected by the right to freedom of opinion. This is based on the previous arguments and is in line with the jurisprudence below so no individual fundamental legal character of this right can be identified.

\subsection{Cases Pertaining to Freedom of Arts in the Hungarian Legal System}

The scope of artistic freedom cannot be claimed to be in any way broader than the scope of the right to freedom of opinion based on legislation, jurisprudence and the related intentions of the Constitutional Court. If legal proceedings are launched in connection with a work of

35 Constitutional Court decision no 24/1996. (VI. 25.) AB, Statement of Reasons, s II.1.

36 Constitutional Court decision no 4/1993. (II. 12.) AB, Statement of Reasons, s I.1.a).

37 Constitutional Court decision no 30/1992. (V. 26.) AB, Statement of Reasons, s III.2.1.

38 Constitutional Court decision no 4/1993. (II. 12.) AB, Statement of Reasons, s I.1.b). 
art or a piece of literature, the courts and constitutional courts will then define the boundaries of freedom in line with the principles and rules established pertaining to freedom of opinion. Artistic expression or literature do have specificities that might influence the decision but this only means that art, in the best case scenario, is treated as a sort of specific opinion, as the expression of opinion also has other specific, non-artistic forms, that is, artistic freedom is not $a b$ ovo more wide-ranging than freedom of opinion. Where the limitation of freedom is a firm and more or less prompt response of the law, e.g. the punishment of a graffiti artist for wilful damage or a ban on child pornography, arguments based on artistic values are not very promising in a legal procedure.

\subsubsection{Protection of Reputation and Honour}

A film called Elment az Öszöd puts the figure of Ferenc Gyurcsány, the previous Prime Minister into a context which is fictitious but based on reality. In the film, after the memorable events of the Autumn of 2006, the demonstrations and riots organised after the Prime Minister's 'Öszöd speech', Gyurcsány is sentenced by a court and is seen in handcuffs in one of the scenes. The former Prime Minister complained that his human dignity, honour and good reputation had been damaged because the film expressed unfounded facts and an offensive opinion of him. The claim was rejected by the court of first instance and the Budapest Court of Appeal also rejected his appeal under BDT2015.3326.

The court ruled that processing facts through the means of cinematography requires a specific judgement - a feature film will necessarily contain fictitious elements:

[I]t is clear to the understanding analyst and the average viewer that the defendant did not process the events with the purpose of fact-finding in a chronological order with historical loyalty to reality but created a new, fictitious story suspending real chronology and deviating from the real story-line. For this purpose and for this storyline, they also made use of the real figure of the plaintiff as played by an actor. Due to the specificities of the genre created by the defendant, the artist cannot be held liable for developing the story line format variance with reality.

However, an opinion on public life may also be expressed using the tools of fiction:

Based on the film, it can be undisputedly established that the defendant, as an artist, is of the opinion that the criminal liability of the plaintiff may at least be considered due to the events of recent history. This is the essential message of the film. The defendant cannot be deprived of such a view because that would constitute the restriction of artistic freedom.

In summary:

The defendant depicted the options to examine the liability of the plaintiff related to certain events and, by doing so, they expressed their opinion concerning the real activities carried out by the plaintiff in public life. In the course of expressing their opinion, the defendant did not expose the plaintiff to unjustified humiliation in a way that damaged theirs human dignity. The activities of the defendant are granted protection by the Fundamental Law and they did not damage the rights relating to the personality of the plaintiff. 
It should be noted that a work of art containing fictitious elements might violate personality rights, if the character can be identified with a real person, ie the reason the Court rejected the appeal was not based on the premises that a fictitious work of art $a b$ ovo cannot violate law but because the expression of an opinion on public life as depicted in the film did not go beyond the boundaries of freedom of expression as regards the exposure of public figures to criticism. This is referred to by the ratio decidendi in the header of the judgment - 'Freedom of expression based on the opportunities of artistic freedom, if it is not autotelic and does not expose the person concerned to unjustified humiliation and does not damage their human dignity, is an act protected by the Fundamental Law, where it does not cause any violation of the right relating to personality.' The decision clearly refers to the tests that opinions on public figures need to be subjected to, with respect to the right to honour and the protection of human dignity ('unjustified humiliation' or the challenge to 'human dignity'). Had it been justified by a higher tolerance threshold for public figures, the opinion expressed in the film might have been adjudged to be subject to restriction. ${ }^{39}$ The lawsuit and the judgement in the lawsuit brought after the publication of Sándor Márai's Egy polgár vallomásai, considered the author's main achievement, is a literary example of the violation of personality rights by fiction. ${ }^{40}$

\subsubsection{Abuse of the Right to One's Own Image}

In a case heard by the Hungarian Supreme Court (decision BH1994.127) caricatures similar to photo montages were published of Ágnes G Nagyné Maczó, a member of Parliament in showing the head of the plaintiff was on another person's body. The magazine wanted to emphasise the powerful, aggressive character of the politician by putting an image of her head on the torso of a body-builder in a swimsuit. The Supreme Court ruled that the plaintiff should be paid damages because the form of depiction 'is offensive to the plaintiff in terms of offending her as a woman and damaging her human dignity'. Later, another political caricature was considered by the court to be a lawful expression of opinion (BH2000.293): A photograph taken of a public figure and qualified as a caricature does not violate the right to one's own image and an opinion expressed in this way does not violate honour or human dignity if it is not unjustifiably harmful, offensive or degrading. The courts considered these cases as questions relating to the freedom of expression and on this basis judged the lawfulness of the opinion, according to the prevailing practices at the time of the decision. Today, the case of Mrs G Nagyné would probably be decided in favour of the magazine based on the principles and practices relating to public figures, which have by now become well established.

\subsubsection{Prohibited Totalitarian Symbols}

Reading the passage of law on the criminal offence termed 'usage of totalitarian symbols,' the impression may be formed that at a certain point, the Hungarian legal regime directly recognised the unique status of artistic expression. Article 269/B of the previous Criminal Code (Act IV of 1978) and Article 335(2) of the new Criminal Code (Act C of 2012), which have the same content, stipulated that any person who uses the symbols proscribed in the legislation 'for the purposes of the dissemination of knowledge, education, science or

39 For more details on the tests, see Koltay (2014) 309-82.

40 Fischer and Sarusi Kiss (2003) 545-80. 
art, or with the purpose of information on events of history or the present time shall not be liable to punishment'. However, it is apparent that the 'artistic purpose' is only applied in certain privileged cases and, due to the character of the punishable act, the legislator rightly decided to exempt certain ways of usage from the ban. In addition to art, these include the use of banned symbols for the purposes of the dissemination of knowledge, education or information, ie every communication or creation where, for various reasons, it is justified to leave the opportunity to use symbols of despotism open. The work of art here is again 'only' one of the opinions to be judged specifically and it does not enjoy ab ovo a broader scope of protection than other opinions do but rather has to be judged in the same way as other opinions which are of outstanding importance for society (for the purpose of disseminating knowledge, science, education or information). This statement is also emphasised by the currently effective text of the Criminal Code, which was developed as a result of Constitutional Court Decision 4/2013. (II. 21.) AB repealing the original provision, which no longer mentions privileged opinions, but which includes the notion of 'capable of disturbing public order' to describe the use of symbols of despotism as a condition for criminal liability. From this, it is clear that the specific opinions referred to in the previous paragraph (2) - including works of art - will continue to be exempt as they are not capable of disturbing public order.

\subsubsection{The Protection of National Symbols}

Article 334 of the new Criminal Code, similarly to Article 269/A. of the previous one grants protection to Hungarian national symbols - 'Any person who publicly uses an expression offending or denigrating the national anthem, the flag or the coat of arms of the Republic of Hungary or the Holy Crown, or insults them in any other way, unless a graver crime is realised, shall be liable to punishment for a misdemeanour by imprisonment of up to one year.' Constitutional Court decision 13/2000. (V. 12.) AB discussed the constitutionality of this provision and rejected the motion to annul it; nevertheless as the statement of reasons stipulates:

$[\mathrm{N}]$ egative opinions and scientific views on the history, value and public law significance of symbols and scientific views, artistic expressions or the expression of criticism and the expression of proposals to change or ban them shall not reasonably fall under criminal sanctioning, but shall constitute parts of the constitutional freedom of opinion. ${ }^{41}$

Opinions, criticisms, scientific views and proposals are therefore to be granted protection in the same way as artistic expression is, in accordance with the general principles of freedom of opinion.

\subsubsection{Summary}

Legislation mostly remains silent on granting differentiated protection to artistic expression in a way that differs from the protection granted to the freedom of opinion and where it does/did expressly mention it, e.g. with respect to crime relating to the use of symbols of despotism, it was identified as one of several specific types of expression. The jurisprudence

${ }^{41}$ Constitutional Court decision no 13/2000. (V. 12.) AB, Statement of Reasons, s IV.6. 
of necessity encounters cases launched or triggered by works of art and pieces of literature but, without exception, it applies the relevant standards of freedom of opinion (established in the area of rights relating to personality or hate speech). Artistic expression is a specific form of expression of opinion and, for jurisprudence to be sound, it is important to take these specificities into account, e.g. a literary work or a film can be assumed to be fictitious and thus does not aim to depict or present reality and real facts, but this does not place works of art out of the context of freedom of opinion and their specificities due to their artistic nature does not exclude the application of certain restrictions on freedom of opinion as they are also specified pertaining to non-artistic opinions. In the same way, clearly nonartistic opinions might have specificities to be taken into account when establishing the extent to which freedom should be granted, e.g. non-verbal communication in US legal terminology: cases of symbolic speech. ${ }^{42}$ The subjective aspect of artistic freedom is therefore adjusted to the scope of freedom of opinion.

\section{CONCLUSIONS}

The presented arguments can be briefly summarised as artistic freedom, as an independent fundamental right, does not exist and this does not present a problem at all. Certainly, the previous statement can only be accepted as true under some constraints. The subjective side of the artistic freedom in reality integrates into the fundamental right of freedom of opinion, ie artistic expression is free, but it does not require a separate, specific protection under the fundamental law. However, the specificities of artistic expression as factors influencing the scope of the freedom of opinion might be taken into account, e.g. symbolic speech, the specificities of a genre or the time elapsed since publication). Hence, works of art and literary pieces are to be treated as specific, unique opinions - they are presented as a form of freedom of opinion but this does not go beyond the boundaries of freedom of opinion as a fundamental right.

At the same time, the regulation of art, irrespective of this, might be justified even in the Fundamental Law. Setting requirements for the state (the objective obligation of the state to safeguard the institutions of fundamental law) is a precondition for the birth and preservation of works of art, which constitutes the objective side of artistic freedom without any specific subject and denotes its specific constitutional content (commitment on the part of the state to take decisions in cases pertaining to art, while considering the neutrality of the state and aiming to safeguard artistic pluralism). An interesting specificity of Hungarian constitutional development is that up until 1972, the text of the Constitution only reflected the latter aspect of artistic freedom, ie the institutional protection, of course narrowly formulated in line with the societal system and prevailing ideology of the era. Even after 1972, the prescription of the responsibilities of the state was more clearly and explicitly stipulated in the Constitution than in the subjective side of law. Even today, it would not be outrageous for the Fundamental Law to contain only the objective aspect of artistic freedom, although as a matter of fact, the constitutional redundancy in the partial overlap between Articles IX and $\mathrm{X}$, does not cause any problems of interpretation.

42 See e.g. Texas $v$ Johnson 491 US 397 (1989) (burning of the American flag); RAV v St Paul 505 US 377 (1992) (burning of the cross on private property); Virginia v Black 538 US 343 (2003) (burning of the cross in the backyard of a black family). 
In literature grappling with laying down the theoretical foundation for artistic freedom, various requirements are set forth vis-a-vis the legal system. Generally speaking, these can be divided into two groups of expectations, which are not necessarily mutually exclusive: works of art should be granted at least the same constitutional protection as that of public opinion which enjoys the most powerful protection ${ }^{43}$ and the legal system should acknowledge the importance of art and artistic freedom in its own right; should not treat it as a specific category of public opinions and the law should draw the demarcation lines or the boundaries of its freedom based on its specific features. ${ }^{44}$ The first of these demands can be accepted without any reservation, but if this seems insufficient, we might as well consider how justified the second requirement is. However, the purpose of this paper is not to lay the theoretical foundations of artistic freedom (or to establish the impossibility of such a foundation) but to make an overview of the Hungarian legal system of how artistic freedom is exercised in practice as compared to the freedom of arts usually specifically referred to in constitutions. In practical experience, it can be claimed that certain elements of the second requirement have already become reality. Certain decisions have recognised the specificities of artistic expression (satire, fiction, etc.), or the significance of the way that works of art are received by the audience, e.g. the time elapsed since their publication and the reception and assessment of the work of art by the audience. Art is treated as a sort of specific way of expressing opinion and thus its specificities may be taken into account, as is done in other specific ways of expressing opinions, but the legal judgement of a work of art in all cases remains within the law pertaining to freedom of opinion. The necessary weighing up of colliding rights and conflicting interests needs to be done in that context and the scope or coverage of this freedom can be established on this basis. This should not come as disappointment, because this does not mean at all that art is degraded by the law but on the contrary, the nearly instinctive reluctance of modern law on freedom of expression to draw a separate demarcation line for art may only be beneficial for artists, works of art and audiences alike.

\section{LITERATURE}

Balogh, Zsolt, 'Az Alkotmány fogalmi kultúrája és az alkotmánybíráskodás' (The conceptual culture of the Constitution and the constitutional justice) (1999) 2 Fundamentum 28-38.

Bezanson, Randall P., Art and Freedom of Speech (University of Illinois Press 2009).

Cseporán, Zsolt and Kocsis, Miklós, 'Az Alkotmánybíróság határozata a Magyar Mủvészeti Akadémiáról. A müvészet szabadsága és pluralitása' (Decision of the Constitutional Court on Hungarian Academy of Arts: Freedom and plurality of arts) (2014) 4 Jogesetek Magyarázata 3-8.

Eberle, Edward J., 'Art as Speech' (2007-2008) 1 University of Pennsylvania Journal of Law \& Social Change 1-28.

Fischer, Alajos and Sarusi Kiss, Béla, 'A megcsonkított vallomás (Márai Sándor Egy polgár vallomásainak pere)' (A mutaliated confession [Case of Sándor Márai's The Confessions of a Bourgeois]) (2003) 4-5 Irodalomtörténeti Közlemények 545-80.

Halmai, Gábor, A véleményszabadság határai (Limits of freedom of opinion) (Atlantisz 1994).

Hamilton, Marci A., 'Art Speech' (1996) 49 Vanderbilt Law Review 73-122.

Kearns, Paul, Freedom of Artistic Expression. Essays on Culture and Legal Censure (Hart 2013).

Kearns, Paul, The Legal Concept of Art (Hart 1998).

Kis, János, Az állam semlegessége (State neutrality) (Atlantisz 1997).

43 Eberle (2007-2008) 27-28; Kearns (2013).

44 Hamilton (1996) 104-109; Bezanson (2009) 276-96; Kearns (1998) 40-60. 
Kollarik, Tamás and Vincze, Zsuzsanna, 'Az állami felelősségvállalás, avagy a magyar állam lehetőségei és szerepe az audiovizuális mủvészet támogatásában' (State responsibility, or the state's possibilities of and role in supporting audiovisual arts) in Cseporán, Zsolt (ed), Az alkotás szabadsága és a szerzői jog metszéspontjai (MMA 2016) 53-76.

Koltay, András, 'The Regulation of the Defamation of Public Figures in Europe, with Special Emphasis on the Hungarian Legal System' in Koltay, András (ed), Media Freedom and Media Freedom and Regulation in the New Media World (Wolters Kluwer 2014) 309-82.

Láncos, Petra Lea, 'A tudományos és művészeti élet szabadsága' (Freedom of scientific and artistic life) in Jakab, András (ed), Az Alkotmány kommentárja II. (Századvég 2009).

Levinson, Sanford, 'The Tutelary State: 'Censorship', 'Silencing' and the 'Practices of Cultural Regulation' in Post, Robert (ed), Censorship and Silencing: The Practices of Cultural Regulation (Getty Research Institute for the History of Art and the Humanities 1998) 195-220.

Pótó, János, Az emlékeztetés helyei. Emlékmüvek és politika (Loci memoriae: Monuments and politics) (Osiris 2003).

Sólyom, Péter, 'A müvészet szabadsága és az esztétikai ítéletek' (Freedom of art and aesthetic judgments) (2007) 2 Iustum Aequum Salutare, 95-109.

Zeller, Judit, 'A tudomány és a müvészet szabadsága' (Freedom of science and art) in Chronowski, Nóra and others, Magyar alkotmányjog III. Alapvetö jogok (Dialóg Campus 2006). 